\title{
Phytochemical screening and in vivo evaluation of antiulcer properties of secondary metabolites in aqueous extracts of Ficus. thonningii Blume tested on Wistar rats
}

\author{
Estella TEMBE FOKUNANG ${ }^{1}$, Jessica Ketchemen POUGOUE ${ }^{1}$, Borgia NJUNKIO ${ }^{1}$, \\ Joseph NGOUPAYO ${ }^{2}$, Donatien GATSING ${ }^{3}$, Paul TOMKINS ${ }^{4}$ and \\ Charles Ntungwen FOKUNANG ${ }^{*}$
}

\author{
${ }^{l}$ Department of Pharmaco-toxicology and Pharmacokinetics, Faculty of Medicine and Biomedical Sciences, \\ University of Yaoundé 1, Cameroon. \\ ${ }^{2}$ Department of Pharmacognosy and therapeutic Chemistry, Faculty of Medicine and Biomedical Sciences, \\ University of Yaoundé 1, Cameroon. \\ ${ }^{3}$ Department of Biochemistry, Faculty of Science, University of Dschang, Cameroon. \\ ${ }^{4}$ School of Science, Athlone Institute of Technology, County Westmeath, Republic of Cameroon. \\ *Corresponding author; E-mail: charlesfokunang@yahoo.co.uk.; Tel: +237670902446.
}

\begin{abstract}
Peptic ulcer is an important public health problem affecting about $10 \%$ of the world's population. The treatment of this disease is usually long, expensive and less accessibility and affordability of the modern medications by the poor local population. Peptic ulcer represents about $31.65 \%$ of cases of consultation in the gastroenterology services in Cameroon. The constraints to have medication have diverted poor patients to rely on traditional medicine for their health problems. The objective of this study was to identify the major classes of secondary metabolites to evaluate in vivo the anti-ulcer activity of the aqueous extracts of Ficus. thonningii on Wistar rats. The experimental model used to induce the gastric ulcers was absolute ethanol $100 \%$. Thirty rats were used for the preventive and curative activity respectively represented in six groups: one group without treatment, three pretreated groups with the extract at $(125,250$ and $500 \mathrm{mg} / \mathrm{kg}$ ), a group receiving a pretreatment with the reference drug omeprazole $(20 \mathrm{mg} / \mathrm{kg})$ and another receiving a pretreatment with distilled water (control). Antacid activity was investigated through the determination of the FDA minimal buffer capacity. The phytochemical screening of the extract of the bark showed the presence of the saponins, quinones, coumarins, catechic tannins, phlobotanins, anthocyanin, polyphenols, flavonoïds and betacyanes. Investigation of the in vitro antacid activity of $F$. thonningii Blume stem bark hydro-ethanolic extract showed that the plant did not possess antacid activity with a $1.18 \pm 0.11$ minimum buffer capacities after 10 minutes of exposure. In the preventive anti-ulcer study, the percentage protection of the mucous membrane was of $29.80 \%$ with $125 \mathrm{mg} / \mathrm{kg}, 44.27 \%$ with $250 \mathrm{mg} / \mathrm{kg}$ and $81.18 \%$ with $500 \mathrm{mg} / \mathrm{kg}$. This study showed that the hydroethanolic extract of the mixture of the dried bark of Ficus thonningii Blume had a promising gastro-protective activity both preventively and curatively and at $500 \mathrm{mg} / \mathrm{kg}$. The administration of this extract at concentration up to $2000 \mathrm{mg} / \mathrm{kg}$ could have a potential effect of vascular protection and hepatic protection.
\end{abstract}

(C) 2019 International Formulae Group. All rights reserved

Keywords: Ficus thonningii stem bark hydro-ethanolic extract, gastric ulcer, antacid, gastro-protective, Wistar rat. 


\section{INTRODUCTION}

Gastric or duodenal ulcer causes a loss of a small or extended portion of the bowel tissue wall. It is either erosions or abrasions or superficial abrasions that do not reach the muscle layer and which heal without scarring (LIPCORM, 2008; Dongmo et al., 2014; Tembe et al., 2018a). Gastric ulcer which is chronic and recurrent in the majority of cases results from an imbalance between chlorhydro-peptic stressors $(\mathrm{HCl}$, pepsin, and gastrin) and gastric mucosal defences (mucus, bicarbonate, blood flow mucosal cytoprotection) (Yapi et al., 2015; Zakari et al., 2016). Gastric ulcer occurs in case of rupture in the mucosa that allows the pepsin and hydrochloric acid attack the stomach wall. Gastric ulcer is a disease that affects both men and women (Ahur et al., 2010; Nguele et al., 2016).

It represents $31.65 \%$ of cases of consultations in gastroenterology services in Cameroon (Lapinus and Bajer, 2008; Emmanuel et al., 2012). The three most deadly digestive diseases in Cameroon during 2013 were paralytic ileus and intestinal obstruction, peptic ulcer disease, and other digestive diseases (Zapata et al., 2006; Rachael et al., 2013). The annual mortality rate per 100,000 people from peptic ulcer disease in Cameroon has decreased by $21.6 \%$ since 1990, an average of $0.9 \%$ a year (Sandler et al., 2002; 2006, Fokunang et al., 2018).

Treatment of this disease requires in most cases a combination of several molecules with specific mechanisms of action. This treatment has 4 goals: relieve pain, accelerate healing, prevent complications and reduce the frequency of relapses (Brzozowski et al., 2002; Takezomo et al., 2004).The effective treatment using conventional medicines is not usually well attended by patients, due to their high cost and low availability to a large majority of the population, especially those living in rural areas (Awoussong et al., 2015; Djimeli et al., 2017. In many developing countries, the health infrastructure is poor and a large majority of the population, mainly rural, has no access to primary health care and modern medicines (Kumar et al., 2008; Fokunang et al., 2017a). These patients use the resources of traditional herbal medicine as an alternative treatment. However, traditional herbal medicine is facing a number of problems for its vulgarisation including lack of sufficient studies on therapeutic properties as well as toxicity tests that could provide sufficient guarantees for their rational use (Sun et al., 2006; Eteme et al., 2015; Tembe et al., 2018a).

The common wild plant, $F$. thonningii, is extensively used in African ethno medicine for treating a number of disease conditions which include diarrhoea, urinary tract infections, diabetes mellitus, gonorrhoea, respiratory infections, and mental illnesses (Tsague et al., 2016, Vermo et al., 2017). The leaves of $F$. thonningii contains various bioactive compounds which include alkaloids, terpenoids, flavonoids, tannins and active proteins, all of which contribute to its curative properties. In vitro and in vivo pharmacological studies revealed that $F$. thonningii possesses antimicrobial, antidiarrheal, antihelmintic, antioxidant, antiinflammatory and analgesic properties. Scientific research has validated the ethno medicinal claims that $F$. thonningii is useful in disease management (Ibrahim et al., 2008; Ngameni et al., 2016; Fokunang et al., 2017b). However, there is need to continue identifying, isolating and quantifying the active principles and possibly determine the mechanisms underlying the curative properties of its bark ( Kato et al., 2005; Tembe et al., 2016b; Vermo et al., 2017). It is in this context that the current study was conducted to investigate phytochemically screen, in vivo evaluate the anti-ulcer activity of the stem bark extract of Ficus thonningii on Wistar rat models.

\section{MATERIALS AND METHODS}

This was an in vivo experimental preclinical study on Wistar rat models conducted from the $11^{\text {th }}$ November 2016 to the $25^{\text {th }}$ of May 2017. The study was done in the Preclinical Animal toxicology and Pharmacology Laboratory of the Faculty of Medicine and Biological Sciences, of the University of Yaoundé 1, Cameroon. 


\section{Ethical consideration}

Ethical approval was given by the institutional review board (IRB) of the Faculty of Medicine and Biomedical Sciences of the University of Yaoundé 1 and administrative authorization was obtained to conduct study in the animal house of this faculty.

\section{Collection, identification preparation of plant material}

Fresh stem barks were harvested after identification by a botanist from the plant growing at Bafoussam on the $03^{\text {rd }}$ of January 2017. The identified plant was authenticated at the National Herbarium of Cameroon by comparison with a sample having the voucher reference number 444042/HNC. The barks were dried under shade at room temperature for a period of three weeks in order to avoid solar radiations from altering the secondary metabolites. These barks were spread on plastic bags while avoiding their stacking. The barks were turned upside down so as to favour a homogenous drying process. The dried barks were ground in a clean electric grinding machine in such a way as to obtain a fined powder which was stored in an airtight container.

\section{Plant extract preparation}

Three types of extraction procedures were used in order to evaluate the in vivo activity and to select the extract with the best activity since there were no earlier studies with respect to the evaluation of the antiulcer activity of the bark of Ficus thonningii Blume.

\section{Extraction by Maceration, Infusion and decoction.}

In this process, the coarsely powdered crude plant was placed in a stoppered container with the solvent (distilled water, ethanol and hydro-ethanolic solution 50:50) and allowed to stand at room temperature for a period of 48 hours with frequent agitation until the soluble matter has dissolved. The mixture was then strained, and the damp solid materials were pressed, and the combined liquids were purified by filtration using Whatman No 3 paper (Oyono et al., 2014).

By infusion, fresh infusion was prepared by mixing the crude plant for a short period of time of 10 to 15 minutes with initially boiling water (Kisali et al., 2016) and by decoction, the crude plant was boiled in a specified volume of water for a defined time generally 10 to 15 minutes; it was then cooled and filtered. This procedure was suitable for extracting water-soluble, heat-stable constituents. The starting ratio of crude plant to water was fixed, 1:4 or 1:16; the volume was then brought down to one-fourth its original volume by boiling during the extraction procedure and the concentrated extract was filtered (Kisali et al., 2016).

\section{Yield determination of the extract}

The best activity was shown with the hydro-ethanolic maceration hence after 48 hours the macerate was filtered with Whatman No. 3 filtered paper and the collected filtrate was evaporated in an oven at $50{ }^{\circ} \mathrm{C}$. This extract was weighed in order to determine the yield obtained from the initial powder quantity and then stored in an air-tight container for subsequent experimental tests.

\section{Animal testing}

The animals used were white albino rats of the Wistar strain (Rattus norvegicus) aged between two and three months. These animals had an average weight of $178.2 \pm$ $22.09 \mathrm{~g}$ for the antiulcer activity and $125.5 \pm$ $10.14 \mathrm{~g}$ and $119.8 \pm 6.50 \mathrm{~g}$ respectively for the males and the females used in the assessment of acute toxicity. They were raised in the animal house under favourable conditions for their growth and development. The diet consisted of a mixture of corn meal (45\%), wheat flour (20\%), fish meal $(20 \%)$, soybean meal $(10 \%)$, and palm kernel $(5 \%)$, bone flour for calcium intake $(0.98 \%)$, cooking salt $(0.5 \%)$ and vitamin complex $(0.5 \%)$. Two to three times a month, a vitamin complex (Olivitasol, Cedex, France) was added in their water to drink following the OECD guidelines 420 (OECD, 2001). Animal identification was done by cage card and corresponding bold marker body markings and they were maintained in the animal house (Njar et al, 2005).

For animal selection, the animals were subjected to a gross observation to ensure that the selected rats were in good health. Rats 
were randomly selected with respect to body weight for final allotment to the study. The animal environment was made up of natural air conditioned rooms with optimal air changes per hour, relative humidity, temperature and illumination cycles set to $12 \mathrm{~h}$ light and 12 hours dark. The animals were accommodated in groups housed in cages with stainless steel grill top, together with facilities for food and water bottle and bedding of clean paddy husk (Togola et al., 2014).

For administration of the test substance, the plant extract was administered by oral gavage to each rat with $1 \mathrm{ml}$ of the ulcerogenic substance, using an intubation needle fitted onto a syringe of appropriate size. The dose administered to individual rat was calculated according to its body weight recorded on the day of test substance administration. The anti-ulcer reference drug used was omeprazole (OMIZEC) $20 \mathrm{mg}$ batch number 260044 bought in a community pharmacy in Yaoundé, Centre Region of Cameroon.

\section{Phytochemical screening}

The protocol of (Usman et al., 2009) was used to carry out the different chemical tests. This screening process did not only allow us to test and evaluate the various solutions prepared but also to have an idea of the secondary metabolites present in these solutions.

\section{Preventive evaluation}

In order to choose the best method of extraction we did not limit ourselves on the in vitro phytochemical screening but we continued in vivo in such a way as to confirm the results obtained at the end of the screening.

\section{Preparation of the hydro-ethanolic plant extract}

The powder obtained after the grinding period were weighed and then $10 \mathrm{~g}$ of the powder were mixed with several fractions of a 50:50 hydro-ethanolic solution in order to obtain a final solution of $1000 \mathrm{ml}$ in a flat bottomed flask. This mixture was mixed several times within $48 \mathrm{~h}$ of maceration after which the mixture was filtered using
Whatman paper number 3 . The macerate was dried in an oven at $50{ }^{\circ} \mathrm{C}$ for three days. The dried extract obtained was then weighed in order to determine the yield from the initial powder used. The yield (\%) was obtained from the formula below adopted from Usman et al., 2009.

\section{percentage yield \\ $=\frac{\text { mass of the extract obtained }}{\text { mass of the initial plant powder }} * 100$}

\section{Secondary metabolite identification test Alkaloid identification tests}

$>$ Mayer waltz test:

In a test tube with $2 \mathrm{ml}$ of $1 \%$ extract was added 3 to 5 drops of the Valse Mayer reagent (1.36 $\mathrm{g}$ of $\mathrm{HgCl} 2$ (silver chloride) and $5 \mathrm{~g}$ of KI (iodide of Potassium) and made to a final volume of $100 \mathrm{ml}$ with distilled water. The obtaining of a creamy white precipitate or White-yellow indicated the presence of alkaloids. Test was done using the Mayer Waltz test (Margaret et al., 2012), Hager Test and the Wagner test respectively (Hagazi et al., 2002).

\section{Polyphenol identification}

The test was done using the Iron per chloride test (Togola et al., 2014), lead acetate test. In a test tube was added $2 \mathrm{ml}$ of the $1 \%$ extract followed by a few drops of plead acetate to $10 \%$. The formation of a white precipitate indicated the presence of polyphenols.

\section{Flavonoid identification tests}

In a test tube, $2 \mathrm{ml}$ of the $1 \%$ extract was poured and a few drops of Sulfuric acid added by allowing them to flow over the tube wall. The formation of an orange coloration Orange indicated the presence of flavonoids (Kalaivani, 2013).

\section{Identification test of anthocyanins}

To $5 \mathrm{ml}$ of $5 \%$ extract was added $5 \mathrm{ml}$ of $10 \% \mathrm{H}_{2} \mathrm{SO}_{4}$ and then $5 \mathrm{ml}$ of ammonium hydroxide $\left(\mathrm{NH}_{4} \mathrm{OH}\right)$ was diluted to half. In the presence of anthocyanin, the colouring was accentuated by acidification then turn to bluepurplish in basic medium (Mainen et al., 2014).

Test for identification of tannin $\left(\mathrm{FeCl}_{3} \mathrm{Test}\right)$

In a test tube was introduced $5 \mathrm{ml}$ of the $5 \%$ infused in which was added $1 \mathrm{ml}$ of 
dilute aqueous solution of $1 \%$ ferric perchloride $\left(\mathrm{FeCl}_{3}\right)$. The presence of Tannins was indicated by blackish-blue or greenish coloration (Repetto and Llesuy 2002).

\section{Differentiation of catechic and gallic tannins}

It was obtained by the reaction of STIASNY, which was carried out in the following manner. To $30 \mathrm{ml}$ of infused, was added $15 \mathrm{ml}$ of STIASNY reagent $(10 \mathrm{ml}$ of $40 \%$ formalin more $5 \mathrm{ml}$ of concentrated $\mathrm{HCl}$ ) and heated for 15 minutes in a water bath at $90{ }^{\circ} \mathrm{C}$ following the procedure of Rosette and Rice, (2004). Catechic tannins were obtained by the presence of a precipitate. The obtaining of precipitate showed their presence;

Gallic Tannins: After filtration, the filtrate sodium acetate powder was saturated, and then $1 \mathrm{ml}$ of a solution of $1 \%$ ferric perchloride $\left(\mathrm{FeCl}_{3}\right)$ added. The presence of gallic tannins was not precipitated by the STIASNY reagent was indicated by the development of a shade dark blue (Kato et al., 2005)

\section{Mucilage identification test}

To $1 \mathrm{ml}$ of decoction extract at $10 \%, 5$ $\mathrm{ml}$ of absolute ethanol was added to obtain a precipitate that was fluffy to indicate the presence of mucilages (Hermandez et al., 2000).

\section{Test for the identification of saponins \\ The Foam Test}

$100 \mathrm{ml}$ of the decoction at $1 \%$ were distributed in 10 test tubes numbered successively from 1,2 , and $10 \mathrm{ml}$. The volume of each tube was adjusted to $10 \mathrm{ml}$ with distilled water. Each tube was stirred for 15 seconds in the length direction and then left and allowed to rest for 15 minutes. Observation was done for persistence of the foam (Helbert et al., 2007).

\section{Steroid identification test}

In $1 \mathrm{ml}$ of extract was added $2 \mathrm{ml}$ of acetic anhydride then $2 \mathrm{ml}$ of sulfuric acid to obtain a violet colour turning blue or green indicated the presence of steroids (Repetto and Llesay, 2002).

\section{Test for identification of resins}

In a test tube, was added $2 \mathrm{ml}$ of the $1 \%$ extract and a few drops of solution of anhydrous acetic acid and $1 \mathrm{ml}$ of sulfuric acid $\left(\mathrm{H}_{2} \mathrm{SO}_{4}\right)$ The appearance of a yellow colour indicated the presence of resins.

\section{Test for identification of cardiac glycosides}

In $0.5 \mathrm{ml}$ of the extract were added 2 $\mathrm{ml}$ of glacial acetic acid and a few drops of 5\% Ferric Chloride $\left(\mathrm{FeCl}_{3}\right)$ solution, then $1 \mathrm{ml}$ of concentrated sulfuric acid. The Formation of a greenish or brown ring, at the interface indicated the presence of glycosides heart (Ukwe et al., 2010)

\section{Test for identification of quinones}

In a test tube, $2 \mathrm{ml}$ of $1 \%$ extract was added; $2 \mathrm{ml}$ of concentrated $\mathrm{H}_{2} \mathrm{SO}_{4}$ to obtaining a red colour indicated the presence of the quinones.

\section{Identification test for betacans}

In a test tube, put $2 \mathrm{ml}$ of the $1 \%$ extract. Add $2 \mathrm{ml}$ of $2 \mathrm{~N} \mathrm{NaOH}$ and Heat the tube in a boiling water bath for 5 minutes. The appearance of coloration A yellow color indicated the presence of beta-cyane (Mahmood et al., 2010).

\section{Identification test for coumarins}

In a test tube containing $1 \mathrm{ml}$ of the plant extract was added $1 \mathrm{ml}$ of distilled water and a few drops of $10 \% \mathrm{FeCl}_{3}$. Obtaining a green or blue coloration that turned yellow by addition of nitric acid $\left(\mathrm{HNO}_{3}\right)$ indicated the presence of coumarins (Rachel et al., 2013).

\section{Oxalate identification test}

In a test tube was added $2 \mathrm{ml}$ of the $1 \%$ extract, a few drops of ethanoic acid to obtain a greenish-black color indicating the presence of oxalates (Rosette and Rice, 2004).

\section{In vitro antacid activity}

Evaluation of the total acid neutralization capacity (ANC) according to the United States Pharmacopoeia (USP) 29 (Satya and Paridhavi, 2012).

The samples of the hydro ethanolic extract of the plant of respective weights; $0.5 \mathrm{~g} ; 1 \mathrm{~g}$ as well as $0.25 \mathrm{~g}$ of antacids known as GESTID, RENNIE, MAALOX, sodium bicarbonate were analyzed for the evaluation of their ANC. GESTID, RENNIE, MAALOX tablets were first titrated in the mortar to obtain a powder before the start of the test. Each weighed sample was transferred to a 250 $\mathrm{ml}$ beaker and $30 \mathrm{ml}$ of distilled water was added. The whole was then homogenized with magnetic stirring for 1 minute. The $\mathrm{pH}$ of the solution was measured and recorded. $15 \mathrm{ml}$ of a $1.0 \mathrm{~N} \mathrm{HCl}$ solution was pipetted and poured into the previous solution which was stirred constantly for 15 minutes. The test solution 
was then titrated with an excess of $0.5 \mathrm{~N}$ $\mathrm{NaOH}$ to attain a stable $\mathrm{pH}$ of 3.5. The number of milli equivalents consumed was calculated using this formula: $\mathrm{MEq}$ total $=(15$ $\times \mathrm{NHCl})-(\mathrm{VNaOH} \times \mathrm{NNaOH})$ Where $\mathrm{NHCl}$ and $\mathrm{NNaOH}$ are the normalities of $\mathrm{NaOH}$ and $\mathrm{HCl}$ and $\mathrm{VNaOH}$ the volume of $\mathrm{NaOH}$ required for titration.

\section{Determination of buffer capacity}

The buffer capacity was determined according to the recommended method of (Holbert et al ., 2007). An amount of $0.5 \mathrm{~g}$ of powder from each sample was placed in $25 \mathrm{ml}$ of $0.1 \mathrm{~N} \mathrm{HCl}$ contained in a $50 \mathrm{ml}$ beaker and subjected to constant stirring on a magnetic stirrer. The $\mathrm{pH}$ of the mixture was determined at intervals of $0.5,2,4,6.8$ and 10 minutes. Subsequently, $5 \mathrm{ml}$ of the mixture was removed with a pipette and replaced with $5 \mathrm{ml}$ of $0.1 \mathrm{~N} \mathrm{HCl}$. This process was repeated 10 minutes apart until reaching a $\mathrm{pH}$ below 2, 75 which showed that the buffering capacity of the antacid had been exhausted.

\section{Evaluation of the rate of neutralization of the acid}

The acid neutralization rate was evaluated according to the method of (Rosset and Rice (2004), Usman et al. (2009), on samples of the aqueous extract of the plant and certain antacids such as MAALOX (aluminum hydroxide and magnesium hydroxide) and sodium bicarbonate. $0.5 \mathrm{~g}$ of each standardized drug sample $0.5 \mathrm{~g}$ and $1 \mathrm{~g}$ of the F.thonningii aqueous extract were weighed separately and each put into a $250 \mathrm{ml}$ beaker containing $15 \mathrm{ml}$ of $0.1 \mathrm{~N} \mathrm{HCl}$ and 35 $\mathrm{ml}$ of distilled water with constant stirring. The $\mathrm{pH}$ electrode was immersed in each beaker just after the addition of the sample to be tested. The $0.1 \mathrm{~N}$ hydrochloric acid contained in the burette was continuously added into the beaker at a rate of $2 \mathrm{ml} / \mathrm{min}$. The $\mathrm{pH}$ values were recorded every minute for 60 minutes.

\section{Preparation and administration of the extract}

$200 \mathrm{mg} / \mathrm{ml}$ concentration solution was prepared. $20 \mathrm{~mL}$ of solution was obtained from $4000 \mathrm{mg}$ of extract and distilled water (sufficient for $20 \mathrm{~mL}$ ).Then, the mixture was homogenized using a magnetic stirrer. From this solution, a dose of $2000 \mathrm{mg} / \mathrm{kg}$ of aqueous extract was administered to the male and female test groups according to their weight, while the control groups received distilled water. The animals were again deprived of food for four hours.

\section{Induction of ulcers}

The experimental model used to induce gastric ulcers was the gavage of ethanol described by Mahmood et al (2010). The animals were separated into six groups of five each and were kept in the net cages to avoid coprophagy and were subjected to a 48-hour fast with free access to drinking water (ad libitum). One hour prior to administration of the various solutions, this water was removed. Subsequently, they were divided into six groups of five animals each:

A- The first group of animals received the ulcerogenic substance without the treatment plant;

B- The second group were administered the ulcerogenic substance after treatment with hydro-ethanolic extract of the plant at a dose of $125 \mathrm{mg} / \mathrm{kg}$;

C- The third group were administered the ulcerogenic substance after treatment with hydro-ethanolic extract of the plant at a dose of $250 \mathrm{mg} / \mathrm{kg}$;

D- The fourth group were administered the ulcerogenic substance after treatment with hydro-ethanolic extract of the plant at a dose of $500 \mathrm{mg} / \mathrm{kg}$;

E- The fifth group were administered the ulcerogenic substance after pre-treatment with Omeprazole $20 \mathrm{mg} / \mathrm{kg}$.

F-The sixth group (control) consisted of rats that did not receive the ulcerogenic substance nor the treatment.

\section{Preventive activity}

One hour after administration of these different oral substances, all animals with the exception of the last group of animals were administered $5 \mathrm{~mL} / \mathrm{kg}$ of ethanol at $100 \%$. Knowing the weight of the animals, the volume of solution administered (Va) was determined from the following formula adopted from (Tan and Nyasse, 2000). 
$\mathbf{V a}(\boldsymbol{m L})=\frac{\text { Dose } \frac{\mathrm{mg}}{\mathrm{Kg}} \times \text { weight }(\mathrm{Kg})}{\text { concentration }(\mathrm{mg} / \mathrm{mL})}$

Two hours after alcohol treatment, all animals were anesthetized with excess ether and then sacrificed and dissected.

\section{Curative activity}

The groups A, B, C, D, E received an oral dose of ulcerogenic agent $(1 \mathrm{ml}$ of ethanol solution). After one hour the vehicle, the respective substances were given to each group, $1 \mathrm{ml}$ of distilled water to the negative control group, omeprazole $(20 \mathrm{mg} / \mathrm{kg}$ ) to positive control group and the extract to the test groups were administered. The dosing was given for three days, daily each morning. After six hours the animals were sacrificed, their stomachs were removed and opened along the greater curvature and delicately washed with saline solution so as not to remove the mucous layer from the mucosa surface (Glavin and Szabo, 2003).

Each stomach was ligated to the esophagus and pylorus using sutures and then removed. The contents of the stomach were collected in the Falcon tubes and centrifuged at $3000 \mathrm{rpm}$ for $15 \mathrm{~min}$. The weight of the mucus corresponding to the centrifugation pellet was weighed using a microbalance (Sartorius: Basic), the volume of the gastric juice of the supernatant was measured by means of a graduated test tube. The $\mathrm{pH}$ of each collected gastric juice was measured using a pH meter. Total acidity was determined by titrating the gastric juice with $0.01 \mathrm{~N} \mathrm{NaOH}$ in the presence of phenolphthalein according to the method of Kalaivani et al (2013). The gastric juice is then retained for the determination of pepsin, mucus and total proteins. The stomachs were opened along the large curvature and rinsed with $0.9 \%$ sodium chloride $(\mathrm{NaCl})$ solution. Lesions were measured using a graduated scale and the ulcerated surface (SU) of each rat was determined. The percentage protection (\% P) of the ulcers was determined according to the formula of Njar et al (2005).
$\% \mathrm{P}=\frac{\text { USA of negative control }}{\text { USA of positive control }} \times 100$

The stomach was divided in two; the glandular part was weighed and then deposited in a mortar and titrated with a solution of potassium chloride $(\mathrm{KCl})$ at a rate of $20 \mathrm{~g}$ of stomach for a total volume of $10 \mathrm{ml}$ with $10 \% \mathrm{KCl}$. The solution obtained was centrifuged at $3000 \mathrm{rpm}$ for $15 \mathrm{~min}$ and the supernatant (homogenate) was collected for the determination of the oxidative stress markers.

\section{Quantification of biochemical parameters in gastric juice and homogenates pepsin}

Pepsin was used as a bio marker for the integrity of the gastric mucosa in an acid medium, it hydrolyzed the peptide bonds of the proteins which contained the aromatic amino acids to give the polypeptides which, in the presence of the Folin reagent, gave a violet blue complex which exhibited a maximum absorption at $660 \mathrm{~nm}$. The intensity of the staining was proportional to the amount of polypeptide present in the solution (Anson, 2008; Vemo et al., 2017).

\section{Free mucous}

The quantification of free mucous was done following the procedure described by Hermandez et al. (2013).

\section{Proteins}

The quantification of proteins was done following the procedure described by Nishi et al, 2005. This is demonstrated in the description of protein quantification in Table 1.

\section{Statistical analysis}

The results were expressed in terms of mean \pm standard deviation. The comparisons between the groups were analyzed using oneway analysis of variance, the ANOVA test followed by Turkey's Kramer post hoc test using the Graph Pad Instat version 5.0 software. A P-value of less than 0.05 was considered statistically significant. 
Table 1: Description of the protein quantification.

\begin{tabular}{lll}
\hline Put in the test tubes & Sample & White \\
\hline Sodium hydroxide 0.1N & $190 \mu \mathrm{L}$ & $200 \mu \mathrm{L}$ \\
Gastric juice & $10 \mu \mathrm{L}$ & 1 \\
Solution C & $1000 \mu \mathrm{L}$ & $1000 \mu \mathrm{L}$ \\
Incubate for 10 minutes & $100 \mu \mathrm{L}$ \\
Solution D & \\
The tubes were then vortexed & \\
The tubes were incubated for a period of 30 minutes at room temperature under shade, then read \\
the optical density at 600 nm against the blank.
\end{tabular}

\section{RESULTS}

\section{Extraction Yield}

The extraction yield of the hydroethanolic extract (50:50) of the bark of $F$. thonningii Blume was $17 \%$.

\section{Phytochemical screening}

The hydro-ethanolic extract had the greatest number of secondary metabolites at the end of the phytochemical screening. The phytochemical screening of the extract of the $F$. thonningii stem bark showed the presence of the sapononins, quinones, coumarins, catechic tannins, phlobotanins, anthocyanins, flavonoids and betacyanes as shown in Table 2

\section{Preliminary Testing of Maximum antiulcer effect.}

A maximum anti-ulcer effect was observed with the hydro-ethanolic extract of the bark of $F$. thoninngii Blume, as compared with the other methods of extractions. This is represented in Figure 1 (A-E).

\section{In vitro antacid activity}

At the end of the titration process we did not obtain a $\mathrm{pH}$ of 3.5 hence showing that our plant extract did not have a neutralisation capacity. The buffer capacity and the rate of neutralisation of the acid was not carried out because most of the important parameters used to determine the antacid activity of a substance called the minimal buffering capacity gave us negative results.

\section{Quantification of biochemical parameters FDA Test of antacids}

This test showed that for a period of 10 min the various samples tested with the exception of our plant were capable of maintaining the $\mathrm{pH}$ values above 3 in order to completely neutralize the acid solution. The highest $\mathrm{pH}$ was attained by sodium bicarbonate, followed by that of RENNIE, MAALOX and then GESTID. The hydroethanolic extract of $F$. thonningii Blume did not have an antacid activity. The plant extract of $\mathrm{pH} 1.8 \pm 0.11$ showed no acidic activity when compared with GESTID, RENNIE and MAALOX with $\mathrm{pH}$ above 3 after 10 mins. This test showed that for a period of $10 \mathrm{~min}$ the various samples tested exception of the plant were capable of maintaining the $\mathrm{pH}$ values above 3 in order to completely neutralize the acid solution. The highest $\mathrm{pH}$ was reached by sodium bicarbonate, followed by that of RENNIE, MAALOX and then GESTID. The hydro-ethanolic extract of $F$. thonningii Blume did not have an antacid activity (Table 3).

Protein analysis: There was no significant difference in protein content of the plant extract in the male and female treatments and test control groups as indicated in Figure 2. 


\section{In vivo anti-ulcer activity}

Preventive anti-ulcer activity

The variation of the $\mathrm{pH}$ and the total acidity study showed that $\mathrm{pH}$ and total acidity of the gastric juice varied in animals receiving $500 \mathrm{mg} / \mathrm{kg}$ of extract compared with the negative control. In animals receiving omeprazole, the $\mathrm{pH}$ and total acidity of the gastric juice was almost similar to that of the negative control. There was a significant increase in the $\mathrm{pH}$ of omeprazole (a) $\mathrm{P}>0.05$; (b) $\mathrm{P}>0,01)$ as compared with the negative control (Table 4).

\section{Curative activity}

Effect of the hydro-ethanolic extract of $F$. thonningii Blume on the TSA and the \% I

The $500 \mathrm{mg} / \mathrm{Kg}$ had the highest percentage inhibition of ulcers as compared with the negative group and the other test groups. The cyto-protective effect of the hydro-ethanolic extract of $F$. thonningii Blume showed that there was a significant decrease in the ulcer surface area in the $500 \mathrm{mg} / \mathrm{Kg}$ group as compared with the negative control group (Table 5). A dose-dependent inhibition coupled with a dose-dependent increase in the percentage of protection was observed. The percentage of ulcer protection was higher in the $500 \mathrm{mg} / \mathrm{kg}$ group than in the omeprazole group at $20 \mathrm{mg} / \mathrm{kg}$ (Table 5).

The stomach cross section to show that the percentage of ulcer protection was higher in the $500 \mathrm{mg} / \mathrm{kg}$ group than in the omeprazole group at $20 \mathrm{mg} / \mathrm{kg}$ has been demonstrated in Figure 3, with the pictures of the dissected stomachs of the different groups of rats after ulcer induction with absolute alcohol during the curative effect evaluation (Figure 3).

Variation of the pepsin concentration, mucus concentration and gastric juice

There was a significant decrease in the mucus and gastric juice in the group of animals that received omeprazole and the healthy group (Table 6).

Table 2: Presentation of the secondary metabolites in the aqueous extract of the bark of $F$. thonningii Blume.

\begin{tabular}{|c|c|c|c|c|c|c|}
\hline Test & Specific test & Decoction & Infusion & $\begin{array}{l}\text { Ethanolic } \\
\text { maceration }\end{array}$ & $\begin{array}{l}\text { Hydroethanoli } \\
\text { c maceration }\end{array}$ & $\begin{array}{c}\text { Aqueous } \\
\text { maceration }\end{array}$ \\
\hline \multirow[t]{2}{*}{ Polyphenols } & $\mathrm{FeCl}_{3}$ & ++++ & ++++ & + & ++ & + \\
\hline & Lead acetate & +++ & ++ & ++ & ++ & - \\
\hline Saponin & distilled water & + & ++ & +++ & ++ & - \\
\hline Mucilage & absolute EtOH & - & - & - & - & - \\
\hline \multirow{3}{*}{ Alkaloids } & Wagner & - & - & + & + & - \\
\hline & Mayer & - & - & + & + & - \\
\hline & Hager & - & - & + & + & - \\
\hline \multirow[b]{2}{*}{ Flavonoids } & $\mathrm{NaOH}$ & + & + & + & + & - \\
\hline & $\mathrm{H}_{2} \mathrm{SO}_{4}$ & + & + & + & ++ & + \\
\hline \multirow{3}{*}{ Tannins } & $\mathrm{Cu}_{2} \mathrm{SO}_{4} / \mathrm{NH}_{3}$ & + & + & + & ++ & - \\
\hline & Catechic & + & + & + & + & - \\
\hline & Gallic & - & - & - & - & - \\
\hline Steroids & Acetic anhydride & - & - & - & - & - \\
\hline \multirow[b]{2}{*}{ Coumarines } & $\mathrm{FeCl}_{3}$ & + & + & - & - & - \\
\hline & $\mathrm{HNO}_{3}$ & + & + & + & + & - \\
\hline Oxalate & Ethanoic acid & - & - & - & - & - \\
\hline Quinones & $\mathrm{H}_{2} \mathrm{SO}_{4}$ & + & + & - & + & + \\
\hline
\end{tabular}




\begin{tabular}{llllllll}
\hline Betacyane & $\mathrm{NaOH}$ & - & - & - & - & - \\
\hline Phlobotannins & $\mathrm{HCl}$ & + & + & + & + & - \\
\hline Anthocyane & $\mathrm{H}_{2} \mathrm{SO}_{4}, \mathrm{NH}_{4} \mathrm{OH}$ & + & + & + & + & - \\
\hline C Glycosides & glacial acetic acid & - & - & - & - & - \\
\hline Resins & anhydrous acetic acid & + & + & - & - & -
\end{tabular}

- represents the absence of metabolites, + represents the presence of metabolites, ++ abundant and +++ very abundant, ++++ extremely abundant

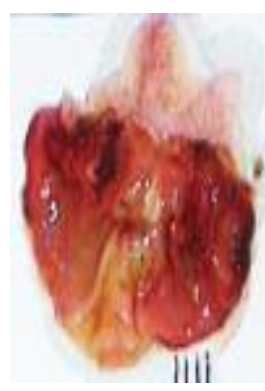

A

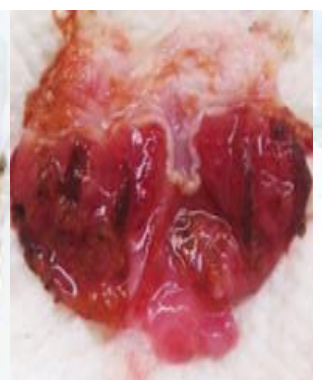

B

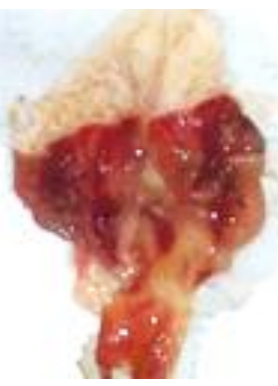

C

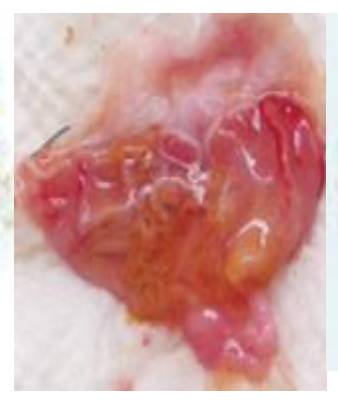

$\mathrm{D}$

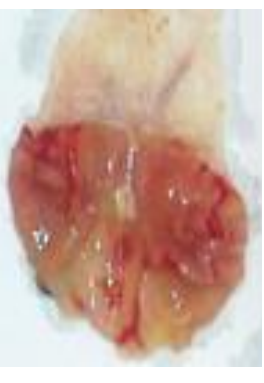

E

Figure 1: photos of dissected stomach after inducing ulcers by absolute alcohol in pretreated rats with the different methods of extraction of the bark of $F$. thonningii: decoction A, infusion B, ethanolic maceration $\mathrm{C}$, hydro-ethanolic maceration $\mathrm{D}$, aqueous maceration $\mathrm{E}$.

Table 3: The FDA minimal neutralisation capacity of the different test substances.

\begin{tabular}{ll}
\hline FDA Test & pH after $\mathbf{1 0}$ minutes \\
\hline Plant & $1.81 \pm 0.11$ \\
GESTID & $3.90 \pm 0.02$ \\
RENNIE & $7.21 \pm 0.47$ \\
MAALOX & $5.17 \pm 0.26$ \\
Sodium bicarbonate & $8.50 \pm 0.18$ \\
HCL + distilled water $(\mathbf{0 . 5 N})$ & $1.41 \pm 0.01$ \\
\hline
\end{tabular}

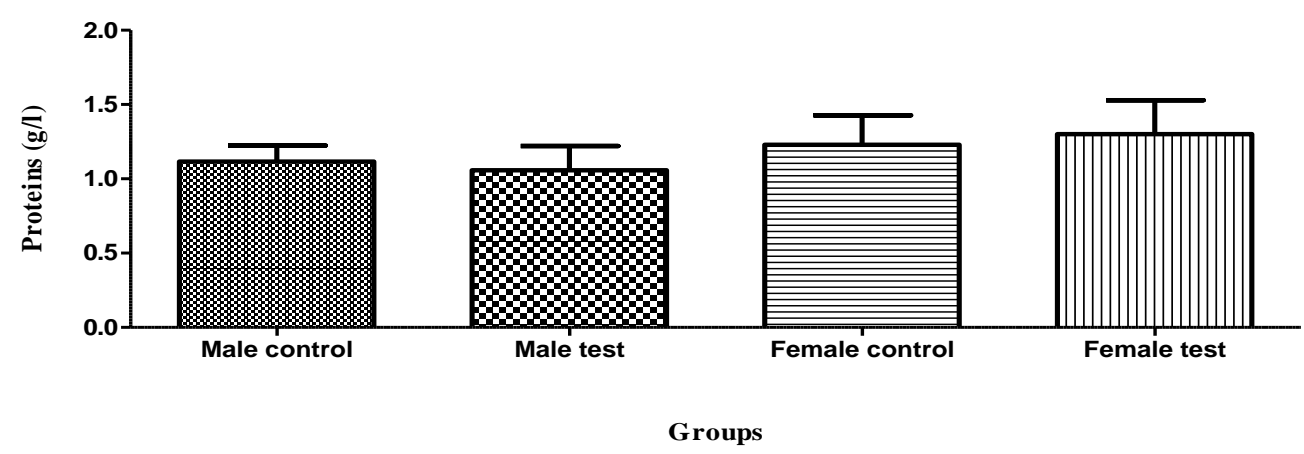

Figure 2: Effect of the hydro-ethanolic extract of $F$. thonningii Blume on the concentration of total proteins $(\mathrm{P}<0.05)$. 
Table 4: Effect of the hydro-ethanolic extract of $F$. thonningii Blume on the $\mathrm{pH}$ and the total acidity.

\begin{tabular}{lllllll}
\hline Parameters & $\begin{array}{l}\text { Negative } \\
\text { control }\end{array}$ & $\mathbf{1 2 5 m g / K g}$ & $\mathbf{2 5 0 m g / K g}$ & $\mathbf{5 0 0 m g / K g}$ & $\begin{array}{l}\text { Omeprazole } \\
\mathbf{1 2 5} \mathbf{m g} / \mathbf{K g}\end{array}$ & SHAM \\
& & & & & \\
\hline pH & $6.23 \pm 0.25$ & $6.67 \pm 0.16$ & $6.28 \pm 0.61$ & $5.61 \pm 0.64$ & $7.61 \pm 0.22^{\text {ab }}$ & 0 \\
Total & $1.12 \pm 0.32$ & $0.9 \pm 0.2$ & $1.32 \pm 0.46$ & $1.45 \pm 0.56$ & $1.36 \pm 0.82$ & 0 \\
acidity & & & & & & \\
\hline
\end{tabular}

Table 5: Effect of the hydro-ethanolic extract of on the TSA and \%I.

\begin{tabular}{|c|c|c|c|c|c|c|}
\hline Parameters & $\begin{array}{l}\text { Negative } \\
\text { control }\end{array}$ & $125 \mathrm{mg} / \mathrm{Kg}$ & $250 \mathrm{mg} / \mathrm{Kg}$ & $500 \mathrm{mg} / \mathrm{Kg}$ & $\begin{array}{l}\text { Omeprazole } \\
125 \mathrm{mg} / \mathrm{Kg}\end{array}$ & SHAM \\
\hline $\operatorname{TSA}\left(\mathrm{mm}^{2}\right)$ & $257.8 \pm 108.44$ & $193.6 \pm 110.35$ & $153.7 \pm 54.97$ & $51.9 \pm 43.63^{* *}$ & $140.15 \pm 82.03$ & 0 \\
\hline$\%$ I & 0 & 29.80 & 44.27 & 81.18 & 49.18 & 0 \\
\hline
\end{tabular}

Where TSA: total surface area, $\%$ I: percentage inhibition, $* * P<0.01$
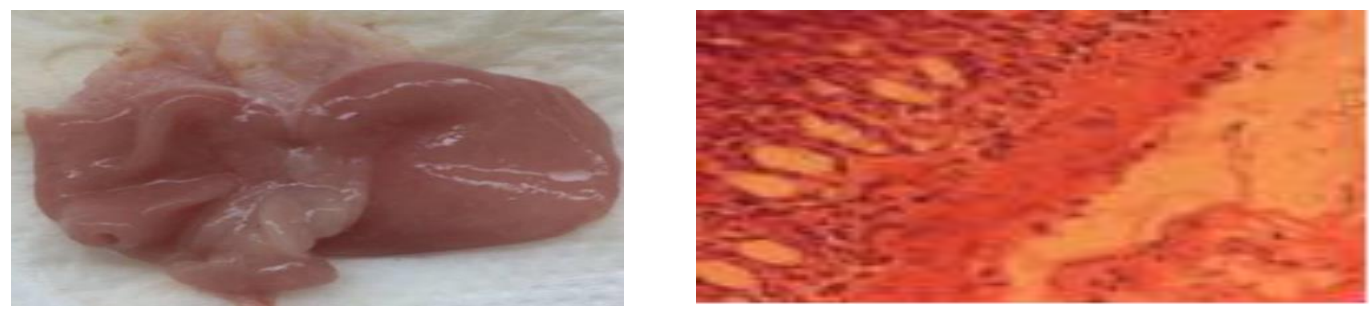

Healthy control (SHAM)
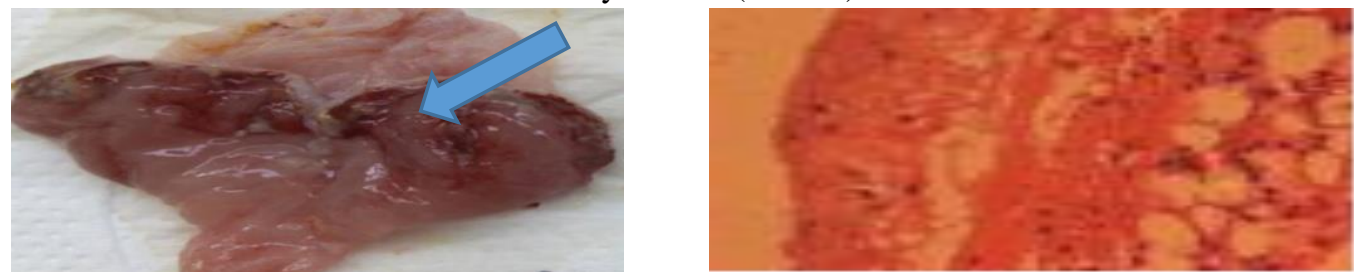

Negative control
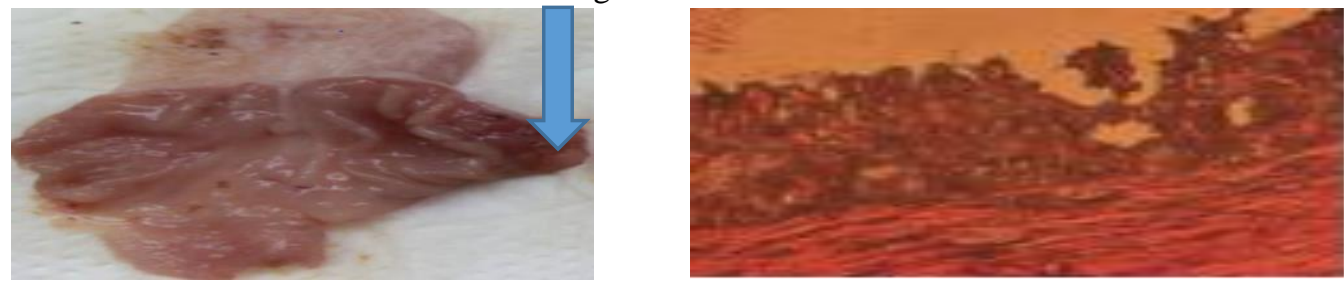

$125 \mathrm{mg} / \mathrm{kg}$ 

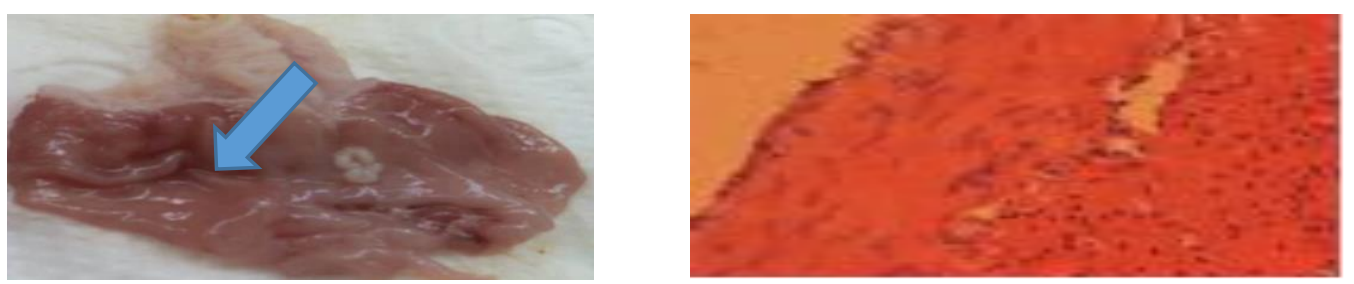

$250 \mathrm{mg} / \mathrm{kg}$
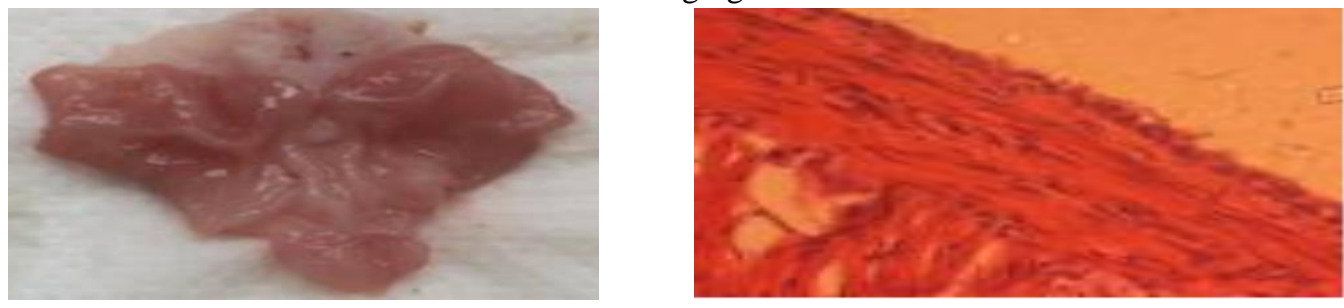

$500 \mathrm{mg} / \mathrm{kg}$
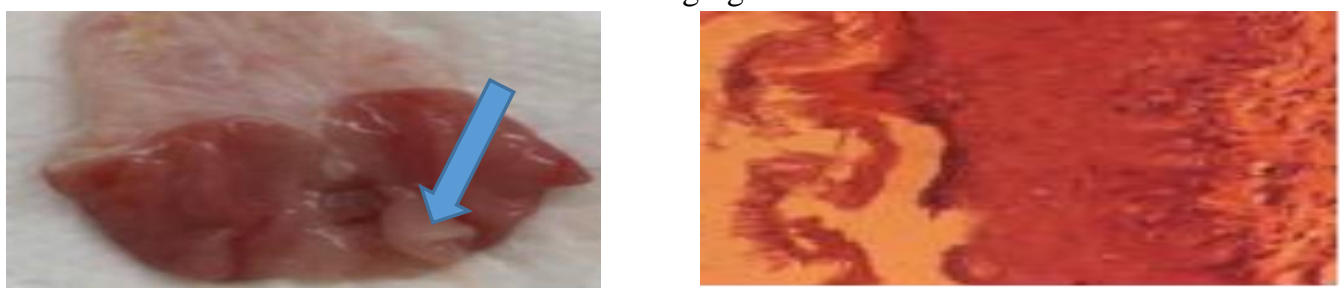

Omeprazole $20 \mathrm{mg} / \mathrm{kg}$

Figure 3: Pictures of the dissected stomachs of the different groups of rats after ulcer induction with absolute alcohol during the curative effect evaluation

Table 6: Effect of the hydro-ethanolic extract of Ficus. thonningii Blume on the concentrations of pepsin and mucus, as well as the gastric juice variation $(\mathrm{P}<0.05)$.

\begin{tabular}{lllllll}
\hline Parameters & $\mathbf{N C}$ & $\mathbf{1 2 5} \mathbf{~ M g} / \mathbf{K g}$ & $\mathbf{2 5 0} \mathbf{~ M g} / \mathbf{K g}$ & $\mathbf{5 0 0} \mathbf{~ M g} / \mathbf{K g}$ & Omp. & HA \\
\hline Pepsine( $\mathbf{\mu m o l} / \mathbf{m g} \mathbf{~ p r})$ & $0,07 \pm 0,02$ & $0,03 \pm 0,02$ & $0,03 \pm 0,01$ & $0,04 \pm 0,04$ & $0,05 \pm 0,02$ & $0,03 \pm 0,02$ \\
& & & & & & \\
& & & & & \\
Mucus (mg/mg pr) & $0,46 \pm 0,13$ & $0,41 \pm 0,08$ & $0,45 \pm 0,07$ & $0,42 \pm 0,08$ & $0,03 \pm 0,02^{* * *}$ & $0,02 \pm 0,05^{* * *}$ \\
Gastric juice (ml) & $5,55 \pm 1,40$ & $4,33 \pm 1,59$ & $4,50 \pm 2,47$ & $3,00 \pm 1,66$ & $5,15 \pm 1,44$ & $0,25 \pm 0,00^{* * *}$ \\
\hline
\end{tabular}
Pr: proteins, NC: negative control, HA: healthy animals, Omp: omeprazole.

\section{DISCUSSION}

Belonging to the family of Moraceae, the genus Ficus is among the largest genera of angiosperms, from about 60 are present in Cameroun. (Ngameni et al., 2016; Tembe et al., 2018). In our search of bioactive compounds from Cameroonian medicinal plants of the Ficus, we examined the hydroethanolic extract of the bark of $F$. thonningii Blume on peptic ulcers induced by absolute ethanol. Ethanol exposes the mucosa to the proteolytic and hydrolytic actions of hydrochloric acid and pepsin (Rosette and
Rice, 2004), causing damage to the membrane (Sener et al., 2004), stimulates acid secretion, increases activity of xanthine oxidase, triggers imbalances in cellular antioxidant processes, reduces mucosa microcirculation and increases apoptosis (Hernandez-Munoz et al., 2000).

In this study, the results of the phytochemical screening showed that the hydro-ethanolic stem bark of $F$. thonningii Blume contained various biologically active compounds called phytochemicals, which are naturally produced by the plant as protection 
against biotic and abiotic stresses. The main groups of phytochemicals isolated from the prepared extract solution included; polyphenols, saponins, alkaloids, flavonoids, catechic tannins, coumarins, quinones, phlobotanins, anthocyanins which corroborates with the work done by Dangarembizi et al. in 2013 on the leaves of F. thonningii (Rachael et al., 2013) and Usman et al.(2009). These metabolites are similar to those found in $F$. sycomorus (Roussos, 2007; Kalaivani and Jegadeesan, 2013). Phytochemicals such as alkaloids have anti-depressive, antibacterial, and antiinflammatory effects in which some have preventive and curative anti-ulcer activities (Mahmood et al., 2010; Kechia et al., 2016;Nahla et al., 2017). Flavonoids favours blood circulation, are antioxidants as well increase the production of prostaglandins in the gastric mucosa (Tan and Nyasse, 2000; Hagazi et al., 2002;Miller and Henagan, 2014). Most of these phytochemicals have an effect on the gastric mucosa which could be responsible of the plant antiulcer activity.

The control of acidity of the stomach in peptic ulcer diseases can be accomplished by several mechanisms such as: neutralization of the existing acid, inhibition of acid secretion, stimulation of natural defense processes, Infection against $\mathrm{H}$. pylori. Antacids are highly used as adjuvants in the therapy of gastric ulcers (Mahmood et al., 2010; Awoussong et al., 2015). The study of the antacid activity of the stem bark of F.thonningii Blume showed that it does not have an antacid activity observed through the FDA minimal buffer capacity since the $\mathrm{pH}$ obtained was $1.81 \pm 0.11$ which is less than 3.5.

The preventive evaluation of the stem bark extract of $F$. thonningii Blume was carried out at the end of which gastric juice was collected in the pylorus and cardiac ligation model and its acid volume, $\mathrm{pH}$, total acidity were estimated. Oral administration of absolute ethanol resulted in the production of gastric lesions on the glandular segment of the stomach. F. thonningii hydro-ethanolic stem bark extract showed significant gastro protective effect against ethanol-induced ulcers at all dose levels (125, 250 and $500 \mathrm{mg} / \mathrm{Kg}$ ) compared with the control groups $(\mathrm{P}<0.05 \%)$. This was shown by a nonsignificant decrease in the $\mathrm{pH}$, total acidity, pepsin, gastric mucous and gastric juice in the test groups as compared to the negative control group. The gastro-protective effect of $F$. thonningii hydro-ethanolic stem bark extract against mucosal damage induced by alcohol could be due to its antioxidant and/or free radical scavenging effects. It has been reported that some bioactive molecules from plants sources can induce gastric ulcer and therefore the need for mass screening of herbal plants for ethnomedicine application in the community (nahla et al., 2017). This result corroborate with those obtained by Mainen et al. (2012) who worked on the grastroprotective effect of the crude ethanol extract of Ethiopian propolis against chemical induced gastric mucosal lesions in mice. At a dose of $500 \mathrm{mg} / \mathrm{Kg}$, the anti-ulcer effect was maximum with a significant reduction of the total surface area and a high percentage of mucosal protection $(81.18 \%)$. In addition, the weight of the free mucus at $500 \mathrm{mg} / \mathrm{kg}$ was lower than that of the negative control. Similar results were reported by Hagazi et al., (2002) which showed that the roots of Zapoteca portoricensis inhibited ulcers induced by absolute alcohol in the ulcer was 93\%. Miller and Henagan, (2014) showed that the mixture Tetrapleura tetraptera and Guibourti aehie inhibited to $91.5 \%$ the ulcers induced by the $\mathrm{HCl} /$ ethanol mixture at 500 $\mathrm{mg} / \mathrm{kg}$.

F. thonningii Blume stem bark hydroethanolic extract at all doses $(125,250$ and $500 \mathrm{mg} / \mathrm{Kg}$ ) have reduced the ulcer total surface area when compared with the negative control group $(\mathrm{P}<0.05)$ where the greatest percentage of inhibition was observed by the $500 \mathrm{mg} / \mathrm{Kg}$ group of rats $(92.94 \%)$ but not significantly. This results did not corroborate with the Curative treatment of detoxified pericarp extract of Anamirta cocculus fruit given orally at a dose of $(200 \mathrm{mg} / \mathrm{kg})$ and roxatidine (positive control) administered at a dose of $(100 \mathrm{mg} / \mathrm{kg})$ which induced a 
significant curative effect. The anti-ulcer drug, roxatidine and detoxified pericarp extract of Anamirta cocculus fruit significantly inhibited ulcer formation by $81.06 \%$ and $54.49 \%$ respectively when compared with control $(\mathrm{p}<0.001)$ (Mahmood et al., 2010; Satya and Paridhavi, 2012). The present finding suggests that $F$. thonningii Blume stem bark hydro-ethanolic extract promote ulcer protection as ascertained by the comparative decrease in ulcer surface area and percentage inhibition of ulcers. In the present alcohol-induced gastric ulcer model, the levels of glutathione, catalase and MDA increased in the $500 \mathrm{mg} / \mathrm{Kg}$ group as compared with the negative control. These compounds are important for maintaining the integrity of the gastric mucosa and mediating the protective effects of prostaglandins against gastric mucosal injury (Miller and Henagan, 2014).In studies of indomethacin induced toxicity rat studies, indomethacin can potentially decrease resistance of gastric barrier to disruption by alcohol.

\section{Conclusion}

Ficus thonningii belonging to the order Hamamelidae and the family Moraceae occupies an important place in African traditional medicine but also in food. In traditional medicine, different parts of F.thonningii are used alone or in combination with other plants in the treatment of several diseases. Thus, the fresh barks of the plant are consumed in the western region of Cameroon to treat gastric ulcers, frequent and recurrent diseases, whose treatment with pharmaceutical specialties is long and costly. We can conclude from this work that the $F$. thonningii stem bark hydro-ethanolic extract contains flavonoids, saponins, quinones, alkaloids, coumarins, catechic tannins, polyphenols, flavonoids, phlebotanins and anthocyanides. The extract fractions inhibited gastric ulcers both preventively and curatively, induced in male rats by absolute ethanol in a dose-dependent manner. At 500 $\mathrm{mg} / \mathrm{kg}$, this extract inhibited ulcers, decreases the weight of free mucus, volume of gastric juice, pepsin concentration. These effects at $500 \mathrm{mg} / \mathrm{kg}$ were superior to those produced by omeprazole at $20 \mathrm{mg} / \mathrm{kg}$. This extract would therefore inhibit ulcers by a gastro-protective, anti-ulcer and antioxidant action and not by an antacid action when administered at $2000 \mathrm{mg} / \mathrm{kg}$, would have a vascular protective effect.

\section{ACKNOWLEDGEMENTS}

This work was partly funded by the Centre for Bio-polymer and Bio-molecular Research, Athlone Institute of Technology, County Westmeath, Republic of Ireland, and the research mobilization grant from the Ministry of Higher Education, Cameroon. Thanks to the Pougoue family for the financial support and the Preclinical Animal Toxicology laboratory for the technical support.

\section{COMPETING INTERESTS}

The authors declare that they have no competing interests.

\section{AUTHORS' CONTRIBUTIONS}

ETF, CNF contributed in the conception of the protocol, JKP, NJ in laboratory analysis and statistics, DG, ETF, $\mathrm{JKP}$, and PT, participated in manuscript writing and data mining. CNF, ETF Principal Investigators of project. All the authors participated in the review of the manuscript.

\section{REFERENCES}

Ahur VM, Madubunyi I, Adenkola AY, Udem SC. 2010. The effect of acetyl acetate extract of Ficus thonningii (Blume) leaves on erythrocyte osmotic fragility and haematological parameters in acetaminophen-treated rats. Com. Clin. Pathol, 10: 1107-1111.

Anson ML.2008. The estimation of pepsin, trypsin, papain, and cathepsin with hemoglobin. J. Gener. Physiol., 22: 7889.

Awoussong PK, Zaharia V, Ngameni B, Kuete V, Ntede HN, Fokunang CN, Abegaz BM, Ngadjui BT. 2015. Heterocycles 26: synthesis, characterisation, and anticancer activity 
of some thiazolic chalcones. Med Chem Res, 24:131-141. DOI 10.1007/s00044014-1096-8.

Brzozowski I, Konturek PC, Brzozowski T, Konturek SJ, Kwiecien S, Pajdot R, Drozoowicz D, Pawlik N, Ptak A. Hahn EG. 2002. Role of prostaglandinees, nitric oxide sensory nerves and gastrinin acceleration of ulcer healing by melantonin and its precursor, Ltrytophan: J Pineal. Res, 32:149-162.

Djimeli NM, Fodouop SPC, Njateng GSS, Fokunang CN, Tala DS, Kengni F, Gatsing D. 2017. Antibacterial activities and toxicological study of the aqueous extract from leaves of Alchornea cordifolia (Euphorbiaceae). BMC. Complem. Alternat. Med, 17:349. DOI 10.1186/s12906-017-1854-5.

Dongmo MSN, Fokunang CN, Fekam FB, Asonganyi T. 2014. Anticonvulsant activity of extracts from six Cameroonian plants traditionally used to treat epilepsy Int. J. Biol. Chem. Sci, 8(6): 2407-2415.

Dongmo MSN, Fokunang CN, Fekam FB, Asonganyi T. 2014. Anticonvulsant activity of extracts from six Cameroonian plants traditionally used to treat epilepsy. Int. J. Biol. Chem. Sci. 8(6): 2407-2415, ISSN 1997-342X (Online), ISSN 1991-8631, DOI: http://dx.doi.org/10.4314/ijbcs.v8i6.4

Emmanuel EH, Mainen JM, Ramadhani SO, Nondo DT, Mwangomo LA, Mahunnah. A. 2012. A study of antimicrobial activity, acute toxicity and cytoprotective effect of a polyherbal extract in a rat ethanol-HCl gastric ulcer model. $B M C$ Res Notes, 5: 546.

Eteme FL, Fokunang CN, Tchuenguem F, Nolna D, Boula A, Ndze VN, Kemadjou G, Tembe-Fokunang EA, Gatsing D. 2015. Epidémiologie moléculaire du Rotavirus du groupe A associé aux gastroentérites chez les enfants de moins de 5 ans dans la ville de Yaoundé (Cameroun). Int. J. Biol. Chem. Sci, 9(5): 2561-2573.

DOI: http://dx.doi.org/10.4314/ijbcs.v9i5.25
Fokunang CN, Hoare G, Tembe-Fokunang E, Ngameni B, Barkwan S, Ngadjui B, Tomkins P. 2018. FT-IR or Raman Spectroscopy Identification of the Molecular Structure of Ficus Ovata Plant Parts Using Different Extraction Solvents. J. Pharmacol. Clin. Res, 5(1): 001-009-555651.

DOI: 10.19080/JPCR.2018.05.555651.

Fokunang CN, Mushagalusa FK, TembeFokunang EA, Ngoupayo J, Ngameni B,.Njinkio LN, Kadima JN, Kechia FA, Atogho BT, Mbacham WF,. Ngadjui BT. 2017a. Phytochemical and zootechnical studies of Physalis peruviana L. leaves exposured to streptozotocin induced diabetic rats. J. Pharmacog. Phytother, 9(8): $123-130, \quad$ DOI: 10.5897/JPP2016.0418, Article Number: 26682D065767

Fokunang CN, Tsafack AR, Tembe-Fokunang EA, Ndifor NA, Njigou AR, Ngameni B. 2017b. In vitro evaluation of the interaction between Amoxicillin and Hydro Ethanolic Extracts of Annickia chlorantha Toxicol, 1(3): 14. DOI: 10.4172/2476-2067.1000133.

Glavin GB, Szabo S. 2003. Experimental gastric mucosal injury: laboratory models reveal mechanisms of pathogenesis and new therapeutic strategies. Faseb J, 3: 825-831.

Hegazi AG, Abdul, El Hady FK. 2002. Egyptian Propolis: Antioxidant, Antimicrobial Activities and Chemical Composition of Propolis from reclaimed lands, Z. Naturforsch., 57: 395-402.

Hernandez-Munoz R, Montiel- Ruiz C, Vazquez-Martinez O. 2000. Gastric mucosal cell proliferation in ethanolinduced chronic mucosal injury is related to oxidative stress and lipid peroxidation in rats. Laboratory Investigation, 80(8): 1161-1169.

Holbert JM, Noble N, Grote IW.2007. Study of antacid buffers time factor in neutralization of gastric acidity. J. Am. Pharm Assoc, 47: 36-49.

Ibrahim G, Abdulmumin S, Musa KY, Yaro AH. 2008. Anticonvulsant activities of 
Crude Flavonoid Fraction of the Stem bark of Ficus sycomorus (Moraceae). J. Pharmacol. Toxicol., 3(5): 351-356.

Kalaivani MJ. 2013. Evaluation of antiulcer activity of ethanolic extract of Madhuca longifolia flowers in experimental rats. Int. J. Sci. Res., 3(6): 2250-3153.

Kasali MF, Fokunang CN, Ngoupayo J, Tembe-Fokunang EA, Ngameni B, Borgia Njinkio BL, Kechia FA, Kadima JM, Tsague MV, Oyono V, Mbacham WF, Ngadjui. BT. 2016. Evaluation of the Antidiabetic Properties of HydroAlcoholic Extract and Its Fractions from Physalis peruviana L. Leaves on Streptozotocin-Induced Diabetic Wistar Rats. J. Dis. Med. Plts, 2(6): 67-73. DOI: 10.11648/j.jdmp.20160206.

Kato S, Aihara E, Yoshii K, Takeuchi P. 2005. Dual action of prostaglandin $E_{2}$ on gastric acid secretion through different EP-receptor subtypes in the rat. Am J Physiol Gastrointest Liver Physiol, 289: G 64-G69.

Kechia FA Teke GN, Ngameni B, Fokunang CN, Dzoyem JP, Kamga HL. 2016. In vitro antifungal activity of Dorstenia mannii leaf extracts (Moraceae). African. J. Biotechnol, 15(3): 62-67. DOI: $\quad$ 10.5897/AJB2015.14659, 205817757001.

http://www.academicjournals.org/AJB.

Kishore DV, Pinto J, Mini KV. 2011. Antiulcer activity of methanolic and aqueous extracts of leaves of Sapindus trifoliatus Linn. Int J Pharm Sci Rev Res, 6(1):2527.

Kumar A, Fuasto PH, Robins CO. 2008. Pathologic Basis of Disease (Seventh edition). Elsevier Publications ; 797-847.

Lapinus N, Bajer B. 2008. Appareil digestif gastro-entérologie, hépatologie, chirurgie viscérale. Edition Masson, Paris: 48.

LIPCORM. 2008. Ulcère gastrique et duodénal, gastrite. Faculté de Médecine Monpellier Nimes, LIPCOMRM, 14. Availableonhttp://www.med.univmontp1 .fr/enseignement/cycle_2/MIB/Ressourc
es_locales/AppDigest/MIB_290_ulcere_ gastriqueduodenalgastrite_word.

Mahmood AA, Mariod AA, Al-Bayaty F, Abdel-Wahab SI. 2010. Antiulcerogenic activity of Gynura procumbens leaf extract against experimentally induced gastric lesions in rats. J. Med. Plants Res, 4(8): 685-691.

Mainen J, Ramadhani SO, Nondo EE, Rogasian LA, Abdul W, Kidukuli A. 2014. Antimicrobial activity, acute toxicity and cytoprotective effect of Crassocephalum vitellinum (Benth) S. Moore extract in a rat ethanol-HCl gastric ulcer model. BMC Res Notes, 4 (7): 91-98.

Margaret OS, Lilian AA, Akindele JA, Oluwole B, Familoni P. 2012. Effect of Flabellaria paniculata Cav. Extracts on gastric ulcer in rats. BMC Complement Altern Med., 12: 168-174.

Miller TA, Henagan JM. 2014. Indomethacin decreases resistance of gastric barrier to disruption by alcohol. Dig. Dis. Sci; 29: 141-149.

Nahla SAL, Wajeeh MH, Al-Henhena SK, Elham BM, Zahedifard KS, Suzita MN, Hapipah MA, Mahmood AA. . 2017. The antiulcer effect of Cibotium barometz leaves in rats with experimentally induced acute gastric ulcer. Drug Des Devel Ther, 11: 9951009.

Ngameni B, Fokunang CN, Ambassa P, Ndifor NA, Tembe-Fokunang EA, Gonsu KH, Kechia FA, Tsafack AR, Akika KO, Ngadjui BT. 2016. Synthesis and Evaluation of Antimicrobial Properties of Some Chalcones. British. J. Pharma Res, 14(2): 1-11. www.sciencedomain.org DOI: 10.9734/BJPR/2016/28243.

Nguele LR, Fokunang CN, Etoundie C, Chakokan RM, Ngondi JL, Tembe EA, Kechia, FA, Ngameni B, Gatsing D, Oben JE.2016. Utilisation des espèces du genre Aframomum aulacocorpus, A. citratum, A. daniellii) pour le contrôle du poids, le profil lipidique et le statut antioxydant chez les rats Wistar nourris 
avec une diète athérogène. Int. J. Biol. Chem. Sci., 10(6): 2575-2586. DOI: http://dx.doi.org/10.4314/ijbcs.v10i6.14.

Nguele RL, Fokunang CN, Etoundi C, Chakokan RM, Ngondi JL, Tembe EA, Kechia FA, Ngameni B, Gatsing D, Oben EJ. 2016. Utilisation des especes $\mathrm{du}$ genre Aframomum (Aframomum aulacocorpus,. A citratum, A. daniellii) pour le contrôle du poids, le profil lipidique et le statut antioxydant chez les rats Wistar nouris avec une diete atherogene. Int. J. Biol. Chem. Sci., 10(6): 2575-2586. DOI: http://dx.doi.org/10.4314/ijbcs.v19i6.14.

Nishi HH, Kestner J, Elm RJ. 2005. Four Methods for Determining Total Protein Compared by Using Purified Protein Fractions from Human serum. Clin. Chem, 31 (1): 95-98.

Njar VCO, Adesanwo JK, Raji Y.2005. Methyl angolensate: the antiulcer agent of the stem bark of Entandrophragma angolense. Planta Med., 61: 91-92.

OECD / OCDE 420 adopted 17 December 2001: OECD Guidelines for the testing of chemicals acute oral toxicity - method by acute toxic class $76 \mathrm{p}$.

Oyono VA, Fokunang CN, Assam JPA, Tsafack P, Mouafo ET, Ngadjui BT, Penlap VB.2014. Acute toxicity studies, antioxidant and in vitro antibacterial activities of extract from the barks of Ricinodendron heudoletti

(Euphorbiaceae). J. Pharmacognos Phytother, 6(4): 47-53.DOI: 10.5897/JPP2014.0312.

http://www.academicjournals.org/JPP.

Rachael D, Kennedy H, Erlwanger DM, Eliton C. 2013. Phytochemistry, pharmacology and ethnomedicinal uses of Ficus thonningii (blume moraceae): A review. Afr J Tradit Complement Altern Med., 10(2): 203-212.

Repetto MG, Llesuy SF. 2002. Antioxidant properties of natural compounds used in popular medicine for gastric ulcers," Brazil. J. Med. Biol. Res., 5: 523-534.
Rossette NE, Rice ML. 2004. Antacid evaluation. Gastroenterology; 26: 490495.

Roussos GG. 2007. Xanthine Oxidase from Bovine Small Intestine, Grossmann L. Moldare K (eds). Academic Press: New York; 23:5-16.

Sandler RS, Everhart JE, Donowitz M, Adams E, Cronin K, Goodman C ... 2002. The burden of selected digestive diseases in the United Sates. Gastroenterology, 122(5): 1500-1511.

Satya V, Paridhavi M. 2012. Evaluation of anti-ulcer activity of detoxified pericarp extract of Anamirta cocculus fruit. Journal of Pharmacy Research, 12: 5474-5480.

Sener G, Paskaloglu K, Anyaanoglu-Dulger G. 2004. Protective effect of increasing doses of famotidine, omeprazole, lansoprazole, and melatonin against ethanol- induced gastric damage in rats. Indian Journal of Pharmacology, 36: 171-174.

Sun H, Fang W WS, Wang WZ, Hu C. 2006. Structure activity relationships of oleanane and ursane-type triterpenoids. Botanical Studies, 47: 339-368.

Takezono Y, Joh T, Oshima T, Suzuki H, Seno K, Yokoyama Y, Alexander JS, Itoh M. 2004. Role of prostaglandins in maintaining gastric mucus cell permeability against acid exposure. $J$ Lab Clin Med, 143:52-58.

Tan PV and Nyasse B. 2000. Anti-ulcer compound from Voacanga africana with possible histamine $\mathrm{H} 2$ receptor blocking activity. Phytomedicine, 7(6): 509-515.

Tembe FE, Pougoue KJ, Ngoupayo J, Njunkio BN, Nguidjoe EM,Tabi YO, Mbong G, Ngameni B, Nubia K, Fokunang CN .2018. Evaluation of the Toxicity of Secondary Metabolites in Aqueous Extracts of Ficus thonningii Blume in Wistar rats. American J. Ethnomed, 5(2): 13-21. DOI: $10.21767 / 2348$ 9502.100013. ISSN 2348-9502

Tembe-Fokunang EA, Fokunang CN, Ngameni B, Barkwan S, Hoare G, Gatsing D, Ngadjui BT, Tomkins P. 
2018. Pre-clinical in vitro investigation of the cytotoxic effect of Ficus species on hepatoma G2 cells using two standard toxicity assays. Int. J. Biol. Chem. Sci., 12(1): 11-23.

Theoduloz C, carrion IB, Pertino MW, Valenzuela D et Schmeda-Hirshmann G 2012. Potential gastro-protective effect of novel cyperenoic acid / quinine derivatives in human cell cultures. Planta Medica, 78(17): 1807-1812.

Togola A, Karabinta K, Dénou A, Haidara M, Sanogo R, Diallo D. 2014. Effet protecteur des feuilles d'Opilia celtidifolia contre l'ulcère induit par l'éthanol chez le rat. Int. J. Biol. Chem. Sci., 8(6): 2416-2423.

Tsague MV, Fokunang CN, Talla E., Djekilamber A, Tembe-Fokunang EA, Ngo LT, Essomba C, Ntchapda F, Sokeng Dongmo S, Oben EJ, Ze Minkande J, Afane Ela A,Temdie GR, Dimo T, Chi FG, Ngadjui BT. 2016. Identification of the Bioactive Compounds Hypotensive Effect in the Ethyl Acetate Extract of Eribroma oblongum (Malvaceae) Stem Bark. J. Dis. Med. Plts, 2(6): 74-82. Http://www.sciencepublishinggroup.com $/ \mathrm{j} / \mathrm{jdmp}$ DOI: 10.11648/j.jdmp.20160206.13

Ukwe CV, Ubaka CM, Adibe MO,. Okonkwo CJ, Akah PA. 2010. Antiulcer activity of roots of Zapoteca portoricensis (Fam. Fabaceae): J. Basic.Clin. Pharm, 12: 1728.

Usman H, Abdulrahman FI, Usman A. 2009. Qualitative phytochemical screening and in vitro antimicrobial effects of methanol stem bark extract of Ficus thonningii (Moraceae). Afr. J. Tradi., Comple. Alt. Med., 6(3): $289-295$.

Vemo BN, Kenfack A, Ngoula F, Kodjio N, Nounamo GA, Megnimeza M, Teguia A. 2017. Effects of ethanol extract of Bersama engleriana leaves on oxidative stress and reproductive parameters in male Guinea pig (Cavia porcellus) exposed to cypermethrin. Int. J. Biol. Chem, Sci., 11(5): 2243-2253. DOI: http://dx.doi.org/10.4314/ijbcs.v11i5.23

Yapi AB, Kassi DJ, N'Guessan BY,Zirihi GN. 2015. Etude ethnobotanique des Asteraceae medicinales vendues sur les marches du district autonome d'Abidjan (Cote d'Ivoire). Int J. Biol. Chem., Sci., 9(6): 2633-2647.

Zakari AH, Mahamadou CI, Hachimou ZTA. 2016. Efficacité de l'huile de neem (Azadirachta indica) et de Bacillus thuringiensis (Biobit 2X) sur la dynamique de la population de Bemisia tabaci (Gennadius 1889) et Helicoverpa armigera (Hubner, 1808) dans une plantation. Int. J. Biol. Chem. Sci., 10(2): 497-505.

DOI: http://dx.doi.org/10.4314/ijbcs.v10i2.4.

Zapata JC, Zepeda GS, Montano LA, Vazquez BE, Jesus VJ Valdovinos AF. 2006. The association of Helicobacter pylori infection and non-steroidal antiinflammatory drugs in peptic ulcer disease. Can. J. Gastroenterol., 20: 277280. 